\title{
How many larvae and nymphs of Amblyomma spp. ticks (Ixodida: Ixodidae) are needed to detect the presence of Rickettsia (Rickettsiales: Rickettsiaceae)?
}

\author{
Gilbert Barrantes* \& Catalina Sánchez-Quirós \\ Escuela de Biología, Ciudad Universitaria Rodrigo Facio, Universidad de Costa Rica; gilbert.barrantes@gmail.com, \\ catasq@gmail.com \\ * Correspondence
}

Received 02-X-2018. Corrected 23-XII-2018. Accepted 17-I-2019.

\begin{abstract}
Tick-borne rickettsiosis is becoming a common emergent disease in many tropical countries, and the rapid detection of this disease could reduce the impact on wild life and public health. Pools of larvae and nymphs, and individual adult ticks are used for detection of Rickettsia species (Rickettsiaceae), but the number of larvae and nymphs in the pools likely affect the probability of detection of Rickettsia spp. We tested whether the number of larvae or nymphs of Amblyomma (Ixodidae) included in the pools affected the probability of detection. The number of larvae in each pool did not affect the probability of detecting Rickettsia spp., but the probability of detection increased rapidly with the number of nymphs. In this study, 20 nymphs are enough to approach a probability of 1 of detecting Rickettsia.
\end{abstract}

Key words: Amblyomma; larva and nymph pools; Rickettsia.

Barrantes, G., \& Sánchez-Quirós, C. (2019). How many larvae and nymphs of Amblyomma spp. ticks (Ixodida: Ixodidae) are needed to detect the presence of Rickettsia (Rickettsiales: Rickettsiaceae)? Revista de Biología Tropical, 67(2) Suplemento, S78-S82.

Rickettsial infection in the wildlife and human communities is rapidly spreading in tropical regions (Parola, et al. 2013; Santibáñez, Portillo, Santibáñez, Palomar, \& Oteo, 2013; Soares et al., 2015). Thereby, its detection and identification of the Rickettsia that infect wild animals and humans is important to propose counter measures that could reduce the risk of infection (Mörner, Obendorf, Artois, \& Woodford, 2002). In nearly all studies, tick samples are obtained directly from their hosts, usually mammals and birds (Parola, et al. 2013; Soares et al., 2015; Martins \& Labruna, 2015; Lopes et al., 2016; Troyo, et al. 2016). This is a direct approach to assess the presence, identity, and hosts of Rickettsia, or other bacteria, but it is a biased sample of the presence and abundance of Rickettsia in the habits used by wild animals in a particular region. Monitoring the presence and abundance or Rickettsia in nature is becoming important since alien strains that could affect wild animals and humans have been detected far from its original distribution (Lopes et al., 2016).

As a first approach to detect Rickettsia in nature we propose a broad screening on larvae and nymphs collected in different habitats and over different time periods. We specifically focused on off-host immature ticks to test if the probability of detecting Rickettsia spp. is affected by the stage (larvae and nymphs), and by the number of larvae or nymphs included in the pools. We expect that the probability of detecting Rickettsia spp. is not affected by the 
number of larvae included in the pools, but this probability should increase with the number of nymphs. This because if the tick female is infected and transovarial transmission occurs, as in some Amblyomma species (Labruna, et al., 2011; Saraiva, et al. 2013), at least some larvae that emerge from this female's eggs are expected to be infected. Similarly, if the female is not infected all larvae emerged from the eggs of this female neither would be infected. Larvae in each pool are likely to come from the same female as they emerged from eggs and stay close together forming dense groups in the field. On the contrary, nymphs in a pool are likely coming from different females that may or may not be infected (Oliver, 1989; Nicholson, Sonenshine, Lane, \& Vilenberg, 2009). Our objectives are to determine the presence of Rickettsia in off-host immature ticks and to test if the probability of detecting Rickettsia increases with the number of ticks included in single pool.

\section{MATERIALS AND METHODS}

Collection of ticks: We collected off-host larvae and nymphs monthly in Palo Verde National Park, northwestern Costa Rica, Guanacaste province $\left(10^{\circ} 21^{\prime} \mathrm{N}, 85^{\circ} 21^{\prime} \mathrm{W}, 50-250\right.$ m elevation) from February 2012 to February 2013. We conducted the monthly sampling to include the possible temporal variation in the phenology of ticks that may be affected by fluctuation in the climatic conditions of the region (Mata \& Echeverría, 2004). We collected ticks by dragging a piece of fabric (a flannel cloth of $1 \mathrm{~m} \times 1.5 \mathrm{~m}$ ) on the litter and herbaceous layer (0-50 $\mathrm{cm}$ above the ground) in seven sites with different vegetation structure (Hartshorn, 1983). Every $2.5 \mathrm{~m}$ we examined the fabric, collected all immature ticks and preserved them in tubes containing $70 \%$ ethanol. We used the key from Vargas (2006) to identify larvae and nymphs to genus level.

Polymerase chain reactions and sequence of DNA form ticks: We extracted DNA from 37 larval pools and 64 nymphal pools from different sampled sites and months using the Nucleospin ${ }^{\circledR}$ Tissue kit (MachereyNagel) following the manufacturer's instructions for animal tissue. To test the effect of number of larvae and nymphs on detection of Rickettsia we made pools with different numbers of larvae (from 3 to 1427) and nymphs (from 3 to 51). We individually processed all tick samples (pools) using routine PCR assay with primers CS $78 \mathrm{~F}$ and CS 323R, designed to amplify a 401-bp conserved fragment of the enzyme citrate synthase ( $g l t A)$ of Rickettsia, which allows identification of the genus Rickettsia (Roux, Rydkina, Eremeeva, \& Raoult, 1997; Labruna, et al. 2004). DNA PCR assays were performed with a final volume of 25 $\mu \mathrm{L}$ per reaction, which included five microliters of DNA extract, following the procedure described by Labruna et al. (2004). Positive and negative controls were included for each reaction. PCR products of the expected sizes were sequenced in an ABI 3730XL Analyzer (Bioneer Sequencing Service, South Korea). We used the Bio Edit program (Hall, 1999) to determine the consensus sequences which were subsequently analyzed by BLAST to confirm the genetic similarity to Rickettsia species. The sequences obtained were aligned for glt $A$ with the corresponding sequences of other Rickettsia species available in GenBank, using the BLASTn searching.

Statistical analyses: To test the effect of the number of larvae or nymphs included in pools on the probability of detecting Rickettsia, we used General Linear Models with a binomial distribution. We run two separate analyses for larvae, the first included pools from 3 to 55 larvae, and the second from 3 to 1427 . Thus, the first group of larvae pools is similar in range to the pools of nymphs. We used the $\mathrm{R}$ statistical language, version 3.0.1 (R Development Core Team, 2014) for analyses.

\section{RESULTS}

After aligning the sequences obtained for the segment of gltA with the corresponding 

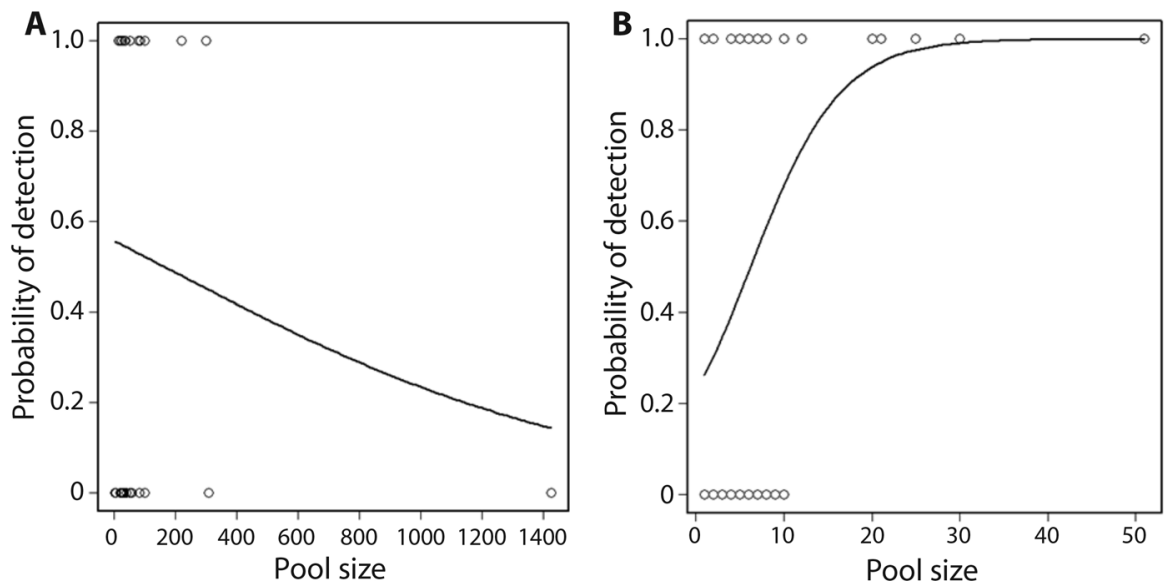

Fig. 1. Probability of detection of Rickettsia as the number of (a) larvae and (b) nymphs in the pools increases.

sequences of other Rickettsia species available in GenBank, we determined that all sequences of larvae and nymph ticks belonged to the genus Rickettsia.

The number of larvae included in the pool samples for both groups did not affect the probability of detecting Rickettsia (group 1: $z=$ $0.09, \mathrm{P}=0.926$; group $2: z=-0.73, \mathrm{P}=0.462$, Table 1, Fig. 1a). However, the probability of detection of Rickettsia in nymphs increased with the number on individuals included in the pool $(z=2.35, \mathrm{P}=0.019$, Fig. $1 b)$. The probability of detecting Rickettsia did not vary among sites (unpubl. data).

\section{DISCUSSION}

Our results are congruent with differences in the biology of larvae and nymphs. Engorged adult females of most tick species free themselves from their hosts to lay their eggs on the litter. All larvae remain together a few days after emerging and then climb the vegetation where they quest for potential hosts (Nicholson

TABLE 1

Effect of the number of larvae and nymphs included in the pools on the probability of detecting Ricketssia spp

\begin{tabular}{|c|c|c|c|c|}
\hline \multirow[b]{2}{*}{ Factor } & \multicolumn{4}{|c|}{ Range of pool size for larvae: $3-55$} \\
\hline & Coefficient & SE & Z-value & $\mathrm{P}$ \\
\hline Intercept & -0.14 & 0.85 & -0.17 & 0.865 \\
\hline \multirow[t]{2}{*}{ Pool size } & 0.00 & 0.02 & 0.09 & 0.926 \\
\hline & \multicolumn{4}{|c|}{ Range of pool size for larvae: $3-1427$} \\
\hline Factor & Coefficient & SE & Z-value & $\mathrm{P}$ \\
\hline Intercept & 0.23 & 0.36 & 0.65 & 0.517 \\
\hline \multirow[t]{2}{*}{ Pool size } & -0.00 & 0.00 & -0.73 & 0.462 \\
\hline & \multicolumn{4}{|c|}{ Range of pool size for nymphs: $3-51$} \\
\hline Factor & Coefficient & SE & Z-value & $P$ \\
\hline Intercept & -1.23 & 0.58 & -2.14 & 0.0325 \\
\hline Pool size & 0.20 & 0.08 & 2.35 & 0.0190 \\
\hline
\end{tabular}

The analyses were conducted for two groups of larvae that differed in the range of larvae included in the pools. 
et al., 2009). Hence, when these free-living larvae are collected, they are usually collected in large groups, from which the pools are selected; thus, the larvae in a pool are likely from the same female. Thus, if the mother is infected, at least some larvae in a pool are also expected to be infected via transovarial transmission, or not at all if the mother is not infected. On the contrary, nymphs collected in the litter or herbaceous layer are not found in dense groups; they are often dispersed and probably from different tick hosts and different mothers (Oliver, 1989), and these factors could affect the probability of the nymphs to be infected.

Based on our data, the number of larvae placed in a pool does not affect the probability of detecting Rickettsia. Thus, a few individuals in each pool would be enough to detect the presence of Rickettsia. However, if the interest is in detecting Rickettsia from nymphs, pools with 10 nymphs yield a probability of detection of about 0.50 , and with 20 nymphs in the pools the probability of detection is close to 1 . In this case, more than 20 nymphs did not improve the probability of detection.

It is important to consider that the probability of detection may change with many different factors, e.g., type of habitat, abundance of ticks, and host abundance (Oorebeek \& Kleindorfer, 2008). However, considering that larvae and nymphs of a large number of ticks have a free-living period, these findings could be useful for ticks collected in different habitats and geographic regions.

Ethical statement: authors declare that they all agree with this publication and made significant contributions; that there is no conflict of interest of any kind; and that we followed all pertinent ethical and legal procedures and requirements. All financial sources are fully and clearly stated in the acknowledgements section. A signed document has been filed in the journal archives.

\section{ACKNOWLEDGMENTS}

This investigation was partially funded by the Vicerrectoría de Investigación, Universidad de Costa Rica; project: B3-079.

\section{RESUMEN}

\begin{abstract}
¿Cuántas larvas y ninfas de la garrapata $\mathrm{Ambl}$ yomma spp. (Ixodida: Ixodidae) se requieren para detectar la presencia de la bacteria Rickettsia (Rickettsiales: Rickettsiaceae)? La rickettsiosis transmitida por garrapatas es una enfermedad emergente cada vez más común en muchos países tropicales, por lo que su rápida detección podría reducir su impacto negativo en la salud humana. Grupos (pozos) de larvas y ninfas de garrapatas, así como individuos adultos son usados para detectar la presencia de diferentes especies de Rickettsia. Sin embargo, el número de larvas y ninfas incluidos en estos grupos probablemente afecta la detección de Rickettsia spp. Nosotros probamos si el número de larvas o ninfas incluidas en estos grupos afecta la probabilidad de detección. Encontramos que el número de larvas incluidas en cada grupo no afectó la probabilidad de detección de Rickettsia spp., pero la probabilidad de detección aumenta rápidamente con el número de ninfas incluidas en los grupos. En este estudio, 20 ninfas por grupo fueron suficientes para tener una probabilidad cercana a 1 de detectar Rickettsia.
\end{abstract}

Palabras clave: Amblyomma; Número de larvas y ninfas; Rickettsia.

\section{REFERENCES}

Hall, T. A. (1999). BioEdit: a user-friendly biological sequence alignment editor and analysis program for Windows 95/98/NT. Nucleic Acids Symposium Series, 41, 95-98.

Hartshorn, G. S. (1983). Plants: introduction. In D. H. Janzen (Ed.), Costa Rican Natural History (p. 118-157). Illinois: University of Chicago Press.

Labruna, M. B., Ogrzewalska, M., Soares, J. F., Martins, T. F., Soares, H. S., Moraes-Filho, J., ... Pinter, A. (2011). Experimental infection of Amblyomma aureolatum ticks with Rickettsia rickettsii. Emerging Infectious Diseases, 17, 829-834.

Labruna, M. B., Whitworth, T., Horta, M., Bouyer, D., McBride, J., Pinter, A., ...Walker, D. (2004). Rickettsia species infecting Amblyomma cooperi ticks from 
an area in the state of São Paulo, Brazil, where Brazilian Spotted Fever is endemic. Journal of Clinical Microbiology, 42, 90-98.

Lopes, M. G., Junior, J. M., Foster, R. J., Harmsen, B. J., Sanchez, E., Thiago F. Martins, T. F., ... Labruna, B. (2016). Ticks and rickettsiae from wildlife in Belize, Central America. Parasites \& Vectors 9, 62. DOI: 10.1186/s13071-016-1348-1

Martins, T. F., \& Labruna, M. B. (2015). Bacteria of the genus Rickettsia in ticks (Acari: Ixodidae) collected from birds in Costa Rica. Ticks and Tick-borne Diseases, 6, 478-82.

Mata, A., \& Echeverría, J. (2004). Introduction. In G. W Frankie, A. Mata, \& S. B. Vinson (Eds.), Biodiversity conservation in Costa Rica (pp. 1-12). Berkeley: University of California Press.

Mörner, T., Obendorf, D. L., Artois, M., \& Woodford, M H. (2002). Surveillance and monitoring of wildlife diseases. Scientific and Technical Review of the Office International des Epizooties, 21, 67-76.

Nicholson, W. I., Sonenshine, D. E., Lane, R. S., \& Vilenberg, G. (2009). Ticks (Ixodida). In G. R., Mullen \& L. A. Durden (Eds.), Medical and Veterinary Entomology (pp. 483-532). Massachusetts: Academic Press.

Oliver, J. H. Jr. (1989). Biology and systematics of ticks (Acari: Ixodida). Annual Review in Ecology and Systematics, 20, 397-430.

Oorebeek, M., \& Kleindorfer, S. (2008). Climate or host availability: what determines the seasonal abundance of ticks? Parasitology Research, 103, 871-875.

Parola, P., Paddock, C. D., Socolovschi, C., Labruna, M. B., Mediannikov, O., Kernif, T., ... Raoult, D. (2013). Update on tick-borne rickettsioses around the world: a geographic approach. Clinical Microbiology Reviews, 4, 657-702.
R Development Core Team. (2014). R: A language and environment for statistical computing. R Foundation for Statistical Computing. Vienna, Austria: R Core Team

Roux, V., Rydkina, E., Eremeeva, M., \& Raoult, D. (1997). Citrate synthase gene comparison, a new tool for phylogenetic analysis and its application for the rickettsiae. International Journal of Systematic Bacteriology, 47, 252-261.

Santibáñez, S., Portillo, A., Santibáñez, P., Palomar, A. M., \& Oteo, J. A. (2013). Usefulness of rickettsial PCR assays for the molecular diagnosis of human rickettsioses. Enfermedades Infecciosas y Microbiología Clínica, 31, 283-288.

Saraiva, D. G., Nieri-Bastos, F. A., Horta, M. C., Soares, H. S., Nicola, P. A., Pereira, L. C., \& Labruna, M. B. (2013). Rickettsia amblyommii infecting Amblyomma auricularium ticks in Pernambuco, northeastern Brazil: isolation, transovarial transmission, and transstadial perpetuation. Vector Borne Zoonotic Diseases, 13, 615-618.

Soares, H. S., Barbieri, A. R., Martins, T. F., Minervino A. H., de Lima, J. T., Marcili A., ... Labruna, M. B. (2015). Ticks and rickettsial infection in the wildlife of two regions of the Brazilian Amazon. Experimental and Applied Acarology, 65, 125-140.

Troyo, A., Moreira-Soto, R. D., Calderón-Arguedas, O., Mata-Somarribas, C., Ortiz-Telloa, J., Barbieri, A. R. M., ... Taylor, L. (2016). Detection of rickettsiae in fleas and ticks from areas of Costa Rica with history of spotted fever group rickettsioses. Ticks and Tickborne Diseases, 7(6), 1128-1134.

Vargas, M., 2006. Clave para los géneros más comunes de larvas de Ixodida (Acari: Ixodidae). Agronomía Costarricense, 30, 101-106. 